Хренова Т. Ю.,

здобувач кафбедри иивільного та господарського права Донецького юридичного інституту МВС України

\title{
УМОВИ ПРИЗНАЧЕННЯ ЖИТЛОВИХ СУБСИДІЙ: СЬОГОДЕННЯ
}

Анотація. У цій статті проаналізовано умови призначення житлових субсидій нині. Зроблено висновок, що, незважаючи на рішучі кроки Уряду в напрямі підвищення адресності й ефективності програми житлових субсидій, постійного вдосконалення законодавства у цій царині, механізм субсидіювання все ж не бездоганний.

Ключові слова: пільгове забезпечення, соціальна підтримка, житлова субсидія, адресність, безповоротність отримання.

Постановка проблеми. Гідне пільгове забезпечення $€$ одним із найважливіших пріоритетів сучасної соціально-правової держави 3 розвинутою ринковою економікою. Кожна цивілізована держава здійснює політику, спрямовану на створення системи соціального забезпечення та охорони здоров'я, працевлаштування населення, підтримку малозабезпечених громадян, недопущення соціальних конфліктів і потрясінь у суспільстві тощо [1, с. 49]. Субсидія як різновид правової пільги виступає юридичним засобом, за допомогою якого в державі створюється специфічний правовий режим, котрий характеризується створенням умов для задоволення інтересів певних категорій осіб у більш сприятливому режимі. Система надання субсидій в Україні діє вже 23 роки. Проте масовості це явище набуло три роки тому після радикального підняття тарифів, у результаті чого кожне друге домогосподарство країни стало не в змозі оплачувати рахунки за житлово-комунальні послуги самостійно, а кількість субсидіантів зросла.

Нині програма житлових субсидій залишається головним механізмом соціального захисту населення в умовах підвищення цін і тарифів на житлово-комунальні послуги.

Питанню житлової субсидії приділяли увагу у своїх дослідженнях як вітчизняні, так і зарубіжні вчені, зокрема А.М. Бабич, Е.Н. Єгоров, Е.Н. Жильцов, Н.А. Кричевський, В.Д. Роїк, А. Армак, У. Беверидж, Л. Ерхард, Дж. М. Кейнс, П. Куусі, Х. Ламперт, Е. Мейо, Л. Рістов, В. Репке та ін.

Мета статті - проаналізувати та зробити висновки щодо умов призначення житлових субсидій нині.

Виклад основного матеріалу дослідження. В умовах політичної нестабільності, кризової економіки, соціальної напруги субсидії, як правові засоби диференціації у механізмі правового регулювання нашої держави, відіграють важливу роль, посідають одне із центральних місць. Головне їх призначення соціальна підтримка певних категорій громадян, які тимчасово опинилися у тяжкому економічному становищі. Соціальна підтримка (піклування) - це система заходів з матеріального забезпечення за рахунок державного та місцевого бюджетів та інших джерел фінансування громадян, які не набули з різних причин юридичного права на пенсії та інші види допомог, але потребують соціальної допомоги і не можуть самостійно вийти зі скрутного становища [2, с. 322]. Надання соціальної підтримки здійснюється на таких засадах: адресність надан- ня; доступність отримання; гуманність у визначенні критеріїв допомоги; цільове використання коштів, передбачених для подання соціальної підтримки; надання соціальної допомоги на підставі встановлених законом соціальних стандартів; безповоротність соціальної підтримки [3, с. 30].

За законодавством України право на отримання житлової субсидії, адресної безготівкової допомоги держави мають сім'ї, чиї витрати на оплату житлово-комунальних послуг (у межах установлених норм споживання та 3 урахуванням пільг) перевищують розмір обов'язкового відсотка платежу.

У зв'язку зі змінами, що відбулися протягом останнього року, умови призначення житлових субсидій суттєво змінилися. Так, 27 квітня 2018 р. Кабінет Міністрів України Постановою № 329 «Про внесення змін до деяких постанов Кабінету Міністрів України та визнання такою, що втратила чинність, постанови Кабінету Міністрів України від 28 грудня 2016 р. № 1022» [4] було внесено зміни до порядку надання пільг та субсидій на оплату житлово-комунальних послуг. Цим нормативно-правовим актом було затверджено нову редакцію «Положення про порядок призначення та надання населенню субсидій для відшкодування витрат на оплату житлово-комунальних послуг, придбання скрапленого газу, твердого та рідкого пічного побутового палива», яке тепер має назву «Положення про порядок надання житлових субсидій».

Відповідно до Положення житлові субсидії призначаються за наявності різниці між розміром плати за житлово-комунальні послуги та/або скраплений газ, тверде та рідке пічне побутове паливо, за абонентське обслуговування для споживачів комунальних послуг, що надаються у багатоквартирних будинках за індивідуальними договорами, внесків за встановлення, обслуговування та заміну вузлів комерційного обліку, внеску/ платежу об'єднанню на оплату витрат на управління багатоквартирним будинком у межах соціальної норми житла, соціальних нормативів житлово-комунальних послуг, скрапленого газу, твердого та рідкого пічного побутового палива, витрат на управління багатоквартирним будинком і розміром обов'язкового відсотка платежу, визначеного в порядку, встановленому Кабінетом Міністрів України.

В окремих випадках за рішеннями комісій, утворених районними, районними у містах Києві і Севастополі держадміністраціями, виконавчими органами міських, районних у містах (у разі їх утворення) рад житлові субсидії непрацездатним непрацюючим особам, які проживають самі, можуть призначатися на норму, яка перевищує встановлену законодавством соціальну норму житла. Відповідно до розглядуваного Положення до таких осіб належать: а) особи, які не досягли повноліття (18 років); б) громадяни, які отримують пенсію за віком або по інвалідності; в) громадяни, які отримують державну соціальну допомогу особі, яка не має права на пенсію, та особам з інвалідністю; г) громадяни, які отримують тим- 
часову державну соціальну допомогу непрацюючій особі, яка досягла загального пенсійного віку, але не набула права на пенсійну виплату.

У разі призначення житлової субсидії особам, доходи яких враховуються під час призначення житлової субсидії, пільги 3 оплати житлово-комунальних послуг, витрат на управління багатоквартирним будинком, придбання скрапленого газу, твердого та рідкого пічного побутового палива не нараховуються протягом періоду отримання житлової субсидії, крім випадку, коли пільговиками є члени сім'ї особи зі складу домогосподарства, які не проживають за адресою домогосподарства.

Указаним Положенням було розширено перелік умов, коли домогосподарство право на субсидію не має, житлова субсидія не призначається (зокрема, на наступний період):

- сім'ям, які більше 2 місяців мають борги за оплату житлово-комунальних послуг. Зокрема, структурним підрозділом 3 питань соціального захисту населення отримано інформацію про наявність простроченої понад два місяці заборгованості з оплати житлово-комунальних послуг, загальна сума якої перевищує 20 неоподатковуваних мінімумів доходів громадян на день звернення за призначенням житлової субсидії (340 грн);

- безробітним працездатного віку, які не стоять на обліку в центрі зайнятості;

- власникам квартир, площа яких перевищує 120 кв. м, i будинків площею понад 200 кв. м (крім дитячих будинків сімейного типу та прийомних сімей, а також сімей, в яких не менше року проживають троє і більше дітей з урахуванням тих, над якими встановлено опіку чи піклування);

- власникам автомобілів преміум-класу, вік яких менше 5 років. Але якщо це бюджетна машина, до того ж взята в розстрочку, іiі власник може розраховувати на субсидію, це має вирішувати спеціальна комісія. При цьому не враховуються транспортні засоби, одержані безоплатно чи придбані на пільгових умовах через структурні підрозділи з питань соціального захисту населення, зокрема за рахунок грошової допомоги на придбання автомобіля. Наявність (відсутність) у власності або володінні зазначених осіб транспортних засобів зазначається у декларації про доходи і витрати осіб, які звернулися за призначенням житлової субсидії. Якщо право власності або володіння на транспортний засіб набуто під час отримання житлової субсидії громадянин, якому призначено житлову субсидію, протягом 30 календарних днів зобов'язаний повідомити про це;

- покупцям земельних ділянок, квартир та інших цінних речей вартістю понад 50 тис. гривень, які придбали це майно протягом 12 місяців перед зверненням за субсидією;

- орендодавцям, які не декларують дохід від зданих квартир. Крім цього, за ухилення від податків їм ще можуть виписати 34 тисячі гривень штрафу;

- тим, хто працює за кордоном або часто відпочиває за межами країни. Але це не стосується службового відрядження, лікування або навчання за умови підтвердження відповідними документами.

Уперше за історію існування програми житлових субсидій право на отримання житлової субсидії нарівні із громадянами України набули також іноземці та особи без громадянства, які на законних підставах перебувають на території України та мешкають у житлових приміщеннях (будинках).

Зазвичай субсидія призначається одному із членів домогосподарства, який зареєстрований і фактично мешкає у житло- вому приміщенні (будинку). В окремих випадках (за рішенням комісіі) субсидія може призначатися:

- орендарю, тобто особі, яка не зареєстрована в житловому приміщенні (будинку), але фактично мешкає у ньому на підставі договору найму (оренди) житла. Так, орендарям житлового приміщення (будинку) житлова субсидія призначається за наявності договору найму (оренди) житла з місяця звернення до дати закінчення опалювального (неопалювального) сезону, але не більше ніж до кінця місяця, в якому закінчується строк дії договору найму (оренди) житла. На наступний строк житлова субсидія призначається за особистим зверненням орендаря;

- індивідуальним забудовникам, будинки яких не прийняті в експлуатацію, але яким нараховується плата за житлово-комунальні послуги;

- внутрішньо переміщеним особам, які не зареєстровані в житловому приміщенні (будинку), але фактично мешкають у ньому без укладеного договору найму (оренди) житла. При цьому їм треба тільки подати заяву та декларацію про доходи.

Слід зазначити, що особи, старші 60 років, яким у зв'язку із недостатнім страховим стажем не призначено пенсію або один із вищезазначених видів державної соціальної допомоги, не можуть претендувати на призначення субсидії на понаднормову площу житла.

Якщо раніше до уваги бралися лише особи, які зареєстровані в домогосподарстві, на яке призначається субсидія, то відтепер у разі призначення субсидії будуть ураховуватися доходи та майновий стан усіх членів сім'”і (відповідно до ст. 3 Сімейного кодексу України [5] сім'ю складають особи, які спільно проживають, пов'язані спільним побутом, мають взаємні права та обов'язки. Подружжя вважається сім'єю і тоді, коли дружина та чоловік у зв'язку з навчанням, роботою, лікуванням, необхідністю догляду за батьками, дітьми та з інших поважних причин не проживають спільно. Дитина належить до сім'ї своїх батьків і тоді, коли спільно з ними не проживає. Сім'я створюється на підставі шлюбу, кровного споріднення, усиновлення, а також на інших підставах, не заборонених законом і таких, що не суперечать моральним засадам суспільства») всіх осіб, які зареєстровані в домогосподарстві.

17 жовтня 2018 р. Урядом були внесені деякі зміни до порядку призначення житлових субсидій населенню [6], які застосовуються 31 жовтня 2018 р.

По-перше, розширено напрями використання субсидії житлові субсидії тепер будуть надаватися також на оплату внесків за встановлення, обслуговування та заміну вузлів комерційного обліку, за абонентське обслуговування для споживачів комунальних послуг, що надаються у багатоквартирних будинках за індивідуальними договорами.

По-друге, розширено перелік осіб, яким субсидія може надаватися:

- на понаднормову площу, яка не може перевищувати більш як на 30\% соціальну норму житла, громадянам: 1) які отримують пенсію у зв'язку з втратою годувальника; 2) які досягли пенсійного віку і отримують пенсію за вислугою років; 3) які отримують державну соціальну допомогу особам з інвалідністю $з$ дитинства та дітям з інвалідністю;

- громадянам, які працюють за кордоном і сплачують там ЄСB, що підтверджується документально (субсидію в Україні домогосподарство, де зареєстрована така особа, має змогу отримати на загальних умовах); 
- робітникам, якщо ЄСВ не сплачується з вини роботодавця;

- студентам, які мешкають у гуртожитку (у розрахунку розміру субсидії доходи батьків не враховуються у разі призначення субсидії студентам, які зареєстровані в гуртожитку за місцем навчання).

По-третє, гранична загальна площа житлового приміщення, на яку призначається субсидія, змінюється на опалювальну площу - житлова субсидія призначається, якщо опалювана площа житлового приміщення не перевищує 120 кв. метрів для квартир у багатоквартирному будинку та 200 кв. метрів для індивідуальних будинків.

По-четверте, за рішенням комісії субсидія може бути призначена у житлових приміщеннях (будинках), на які оформлено два і більше окремих особових рахунків, за умови, що опалювана площа частини житлового приміщення кожного домогосподарства, на яку призначається субсидія, не перевищує 120 кв. метрів для квартири, 200 кв. метрів для індивідуального будинку. Також субсидія також може бути призначена за особливих умов, зокрема, коли: а) особа або інші члени домогосподарства надають соціальні послуги, перебувають у місцях позбавлення волі; б) члени домогосподарств є алко- або наркозалежними, що підтверджується довідкою від лікаря; в) особа мала суму середньомісячної нарахованої заробітної плати менше від розміру мінімальної заробітної плати не більше ніж на 10 відсотків за умови сплати ЄСВ.

При цьому особи, які мають заборгованість по сплаті аліментів, не матимуть субсидії, зокрема вона не призначатиметься, якщо у складі домогосподарства або у складі сім’ї члена домогосподарства є особи, які, за даними Єдиного реєстру боржників, мають заборгованість за виконавчими провадженнями про стягнення аліментів понад 3 місяці (крім осіб, які є алко- або наркозалежними, що підтверджується довідкою від лікаря).

Висновки. Проаналізувавши умови призначення житлових субсидій нині, можемо зробити певні висновки. Зокрема, незважаючи на рішучі кроки Уряду в напрямі підвищення адресності й ефективності програми житлових субсидій, постійного вдосконалення законодавства у цій царині, механізм субсидіювання все ж не бездоганний: а) соціальна підтримка населення, що здійснюється шляхом надання житлових субсидій, є надмірно складною й непрозорою; б) відсутній системний нормативно-правовий акт, який універсально встановлював би підстави, перелік суб'єктів, види та механізм надання такого виду пільг, при цьому наявні нормативно-правові акти містять низку проблемних моментів; в) головна мета Уряду - підтримка малозабезпеченого населення, виконується не повною мірою; г) у результаті підвищення тарифів на оплату житлово-комунальних послуг населення, навіть використовуючи субсидії, змушене сплачувати величезні рахунки. Тому головна ціль держави - покращення економічного становища населення - сьогодні фактично не досягнута.

\section{Jimepamypa:}

1. Бойченко Г.М. Особливості правового регулювання пільгового забезпечення працівників в умовах ринкової економіки: дис. ... канд. юрид. наук: 12.00.05. Луганськ, 2009. 199 с.

2. Прилипко С.М. Предмет права соціального забезпечення: дис. ... д-ра юрид. наук: 12.00.05. Харків, 2007. 382 с.

3. Право соціального забезпечення в Україні: підручник / за заг. ред.: С.М. Прилипка, О.М. Ярошенка. Харків: Вид-во «ФІНН», 2009. $434 \mathrm{c}$.

4. Про внесення змін до деяких постанов Кабінету Міністрів України та визнання такою, що втратила чинність, постанови Кабінету Міністрів України від 28 грудня 2016 р. № 1022: Постанова Кабінету Міністрів України від 27.04.2018 р. № 329. URL: http://zakon.rada.gov.ua/laws/show/329-2018-\%D0\%BF (дата звернення: 08.10.2018)

5. Сімейний кодекс України від 10.01.2002 р. № 2947-III. Відомості Верховної Ради України. 2002. № 21-22. Ст. 135.

6. Про внесення змін до деяких постанов Кабінету Міністрів України: Постанова Кабінету Міністрів України від 17.10.2018 р. № 841. URL: https://www.kmu.gov.ua/ua/npas/pro-vnesennya-zmindo-deyakih-87

Хренова Т. Ю. Условия назначения жилищных субсидий на сегодняшний день

Аннотация. В данной статье проанализированы условия назначения жилищных субсидий на сегодняшний день. Сделан вывод, что, несмотря на решительные шаги правительства в направлении повышения адресности и эффективности программы жилищных субсидий, постоянного совершенствования законодательства в этой области, механизм субсидирования все же не безупречен.

Ключевые слова: льготное обеспечение, социальная поддержка, жилищная субсидия, адресность, безвозвратность получения.

\section{Khrenova T. Terms of the purpose of housing subsidies: present}

Summary. This article analyzes the conditions for the appointment of residential subsidies to date. It was concluded that, despite the Government's decisive steps towards increasing the targeting and effectiveness of the housing subsidy program, and the ongoing improvement of legislation in this area, the subsidy mechanism is still not flawless.

Key words: privileged support, social support, housing subsidy, targeting, irretrievable reception. 